\title{
Islam, Seni Musik, dan Pendidikan Nilai di Pesantren
}

\author{
Sulasman, Fadlil Yani Ainusyamsi \\ Universitas Islam Negeri Sunan Gunung Djati (UIN SGD) Bandung \\ Jl. A.H. Nasution No. 105 Bandung 40614
}

\begin{abstract}
The purpose of this study is to give a description about how the Islam views about art, especially music art. To explain about this purpose, the documentation study is applied in this research. The description is done ontologically, epistemologically, and axiological. For that reasons, we can comprehend what the music is, how characteristic features and ways of working of the music, also we can know how and what for we play music. Furthermore, there will be a new paradigm about music art in the Moslem especially in Pesantren. This research use qualitative method and the result shows that Pesantren as the educational organization of Islam has its own contribution in instilling the values of theological, juridical, Islamic socio-cultural, and sophistical. Sphistical value in Pesantren has been put by purpose for cleansing up the soul. To provide the passion and meaning in the context of deepening enlightenment to students performed the internalization of sophistical values in Pesantren through the music. There are differences about art especially music art in Pesantren between Ulama of Ahlussunah and Ulama of Sufi. Regardless of the controversy between the music is halal or haram, the up growing phenomenon that is there are a many Pesantren which developing the music art. Music in Pesantren is not only just an art but also as a tool of increasing and helping the private and social of Santri.
\end{abstract}

Keywords: Islam, Art, Music, Ulama, Pesantren

\begin{abstract}
ABSTRAK
Penelitian ini bertujuan untuk memberi gambaran bagaimana pandangan Islam tentang seni, khususnya Seni Musik. Untuk menjelaskan tujuan ini, maka digunakan studi pustaka. Penjelasan dilakukan secara ontologis, epistemologis, dan aksiologis. Oleh karena itu, kita akan paham tentang musik, bagaimana ciri-ciri dan cara kerja musik, serta tahu alasan dan tujuan kita bermusik. Dengan demikian maka akan lahir paradigma baru tentang seni musik di kalangan umat Islam khususnya di kalangan pesantren. Metode yang digunakan adalah kualitatif dan hasil penelitian menunjukan bahwa pesantren sebagai lembaga pendidikan Islam telah berjasa dalam menanamkan nilai-nilai teologia, yuridis, sosio kultural Islam, dan nilai sufistik. Nilai sufistik di pesantren ditanamkan dengan tujuan untuk membersihkan kalbu dari segala kotoran jiwa. Untuk memberikan gairah pendalaman serta pemaknaan dalam rangka pencerahan jiwa bagi santri dilakukan internalisasi nilai-nilai sufistik di pesantren melalui musik. Terdapat perbedaan pandangan mengenai seni khususnya seni musik dikalangan pesantren yaitu antara ulama ahlusunnah dan ulama sufi. Terlepas dari kontroversi antara halal dan haram nya musik, banyak pesantren yang mengembangkan seni musik. Musik di pesantren selain untuk seni juga dijadikan alat untuk meningkatkan dan membantu pribadi dan sosial santri.
\end{abstract}

Kata kunci: Islam, Seni, Musik, Ulama, Pesantren 


\section{PENDAHULUAN}

Salah satu "great tradition" di Indonesia adalah pengajaran agama Islam yang muncul di pesantren, yaitu lembaga tradisional pendidikan Islam untuk mempelajari, memahami, mendalami, menghayati dan mengamalkan ajaran Islam dengan menekankan pentingnya moral agama sebagai pedoman perilaku sehari hari (Mastuhu, 1994: 55). Suatu lembaga dikatakan sebuah pesantren jika memenuhi unsur-unsur yang menjadi karakteristiknya yaitu pondok, kyai, masjid, santri dan pengajaran kitab-kitab klasik.

Kehadiran pesantren di tengah masyarakat tidak hanya sebagai lembaga pendidikan, tetapi juga sebagai lembaga penyiaran agama dan sosial keagamaan. Pesantren berhasil menjadikan dirinya sebagai pusat gerakan pengembangan Islam secara universal, termasuk didalamnya pelestarian nilai nilai budaya keislaman. Bahkan pesantren mampu mengembangkan seni-seni tradisi kontemporer, sebagai sarana atau media penanaman nilai di tengah "masyarakat pesantren" tersebut.

Sampai saat ini, seni baik itu seni musik maupun seni rupa masih diperdebatkan di kalanganulama, baikitu kyai pemimpin pesantren maupun kyai diluar pondok pesantren. Perdebatan tentang seni terjadi diantara ulama ahlussunnah yang mengharamkan seni dan ulama sufi yang menghalalkannya. Begitu juga di kalangan pesantren, ada yang mengharamkan dan ada juga yang membolehkan seni.

Topik mengenai Pesantren dan kyai telah banyak menarik perhatian dari para peneliti diantaranya Martin van Bruinessen (1995) yang menulis Kitab Kuning, Pesantren, dan Tarekat. Karel A. Steenbrink (1986) Pesantren, Madrasah, dan Sekolah; Zamakhsyari Dhofier (1982) Tradisi Pesantren: Studi Tentang Pandangan Hidup Kyai; Dawam Rahadjo (1973) Kyai, Pesantren dan Desa; Mastuhu (1994) Dinamika Sistem Pendidikan Pesantren; Hiroko Horikoshi (1987) Kyai dan Perubahan Sosial;
Elly T. Bouwsma ( 1988) Staat Islam en Lokale in West Madura.

Selain masalah Pesantren dan Kyai, para penelitipun banyak yang tertarik menulis tentang seni khususnya seni musik dalam konteks keislaman seperti al-Qardawi (2001) menulis Figh al-Ghina wa al-Musiqy fi DhauI al-Quran wa al-Sunnah; Al-Jauziyah (1991) Kasyfal-Ghina 'an Hukm Sama' al-Ghina; Bunt (1969) Musik Therapy; An Art Beyond Words; Djohan (2006) Terapi Musik: Teori dan Aplikasi; Gazalba (1998) Islam dan Kesenian: Relevansi Islam dan Seni Budaya. Muhaya (2003) Bersufi Melalui Musik: Sebuah Pembelaan Musik Sufi oleh Ahmad Gazali.

Kesenian yang banyak berkembang di pesantren adalah seni lukis berupa kaligrafi, seni bela diri berupa pencak silat, dan seni musik berupa seni qosidah, rebana, marawis, gambus, dan lain-lain. Berkenaan dengan seni musik, tidak sedikit pesantren yang membentuk grup-grup kesenian untuk mengembangkan minat dan bakat para santri. Mereka juga melakukan kolaborasi seni dengan melengkapi peralatan seni modern seperti guitar, organ, dan lain-lain. Selain untuk mengembangkan bakat seni para santri, kesenian di pesantren juga digunakan sebagai media dakwah. Di antara pesantren yang mengembangkan kesenian adalah Pesantren Darusalam di Ciamis dengan mengembangkan Seni Qosidah Burdah dipimpin langsung oleh kyai nya yaitu Dr. K. H. Fadilyani Ainusyamsi, M.Ag., MBA.

Seni digunakan oleh komunitas pesantren sebagai media pengajaran sejarah, hukum, etika, moral, kesederhanaan, dan kesalehan hidup. Banyak kyai dari pesantren dikenal sebagai seniman baik tingkat nasional maupun internasional. Di antaranya adalah K. H. Mustofa Bisri, K. H. D. Zawawi Imron, dan K. H. Maman Imanul Haq. Selain itu ada juga lulusan pesantren yang menjadi seniman terkenal diantaranya Emha Ainun Nadjib, Ahmad Subhanudin Alwi, Jamal D. Rahman dan Acep Zamzam Nur. 
Pandangan Islam tentang kesenian khususnya seni musik, dan peranan seni musik dalam penanaman nilai-nilai di pesantren adalah suatu hal yang cukup menarik untuk menjadi bahan kajian dalam bidang ilmu budaya.

\section{METODE}

Metode yang digunakan adalah kualitatif. Pendekatan ini dipilih karena dianggap relevan dengan karakteristik masalah yang menjadi fokus kajian. Selain itu, metode kualitatif mudah diadaptasikan dengan realitas yang beragam dan saling berinteraksi. Keberagaman dalam penelitian ini, dimaksudkan bahwa dasar musik sufistik tiada lain adalah musik itu sendiri, yang dikemas dalam nuansa religi. Yang dimaksud dengan berinteraksi di sini yaitu adanya kesinambungan dan keterhubungan antara peneliti dengan responden baik secara langsung maupun tidak langsung.

Pemilihan sampel dilakukan oleh penulis secara purposif, hal ini disebabkan karena penulis ingin meningkatkan cakupan dan jarak data yang dicari demi mendapatkan realitas yang berbagai-bagai, sehingga segala temuan akan terlandaskan secara lebih mantap karena prosesnya melibatkan kondisi dan nilai lokal yang semuanya saling mempengaruhi.

Dalam menganalisis data, penulis melakukan analisis data secara induktif. Sebagaimana para peneliti naturalistis, penulis tidak berangkat dari teori a priori, karena teori ini tidak mampu menjelaskan berbagai temuan (realitas dan nilai) yang dihadapi di lapangan yaitu beberapa pondok pesantren di Jawa Barat yang dipilih sebagai objek dalam penelitian penulis adalah Pondok Pesantren Darusalam Ciamis.

\section{HASIL DAN PEMBAHASAN}

\section{Musik Dalam Pandangan Ulama}

Ulama Ahlussunnah mengharamkan seni musik. Mereka lebih mengedepankan nashnash secara langsung dari Al-Quran dan Sunah Rasul SAW. Untuk memperkuat argumennya dalam mengharamkan seni musik, Ulama Ahlussunnah merujuk pada Q.S. Lukman ayat 6: "Dan di antara manusia ada orang yang mempergunakan perkataan yang tidak berguna (Lahw al-hadits) untuk menyesatkan manusia dari jalan Allah tanpa pengetahuan, dan menjadikan jalan Allah itu olok-olokan. Mereka itu akan memperoleh azab yang menghinakan". Selain itu Ulama Ahlussunnah juga merujuk pada beberapa hadits yang diriwayatkan oleh Ibnu Mas'ud, Ibnu Abbas dan Ibnu Umar, bahwa Lahw al-hadits dalam ayat ini adalah lagu (alQardhawy, 2001: 28).

Ulama Tasawuf cenderung menganggap bahwa musik adalah halal. Landasan hukum yang digunakan adalah QS al-Maidah ayat 87: "Hai orang-orang yang beriman, janganlah kamu mengharamkan apa apa yang baik yang telah Allah halalkan bagimu, dan janganlah kamu melampaui batas". Asumsi dasar yang digunakan oleh Ulama Tasawuf adalah 1) musik tidak diharamkan baik oleh Allah SWT maupun Nabi SAW secara tekstual; 2) ada beberapa Hadits yang mengisahkan bahwa Nabi SAW memperkenalkan permainan musik; 3) jika musik digolongkan sebagai Lahw (senda gurau) yang di haramkan, maka semua hal yang bersifat duniawi juga haram hukumnya. Untuk memperkuat argumennya, ulama sufi merujuk pada QS. Muhammad ayat 36: "Sesungguhnya kehidupan dunia ini hanyalah permainan $\left(l a^{\prime} b\right)$ dan senda gurau (Lahw) (al-Qardhawy, 2001: 72).

Terlepas dari perbedaan sudut pandang dan kontroversi antara ulama ahlussunnah dan ulama sufi, al-Qardhawy (2001: 153-157) 
mengambil jalan tengah yakni bahwa musik hukumnya boleh (halal) dengan syarat 1) syair lagu tidak boleh bertentangan dengan syariat; 2) gaya menyanyikan lagu tidak mengundang maksiat; 3) nyanyian tidak dibarengi dengan sesuatu yang diharamkan; dan 4) tidak berlebihan dalam mendengarkannya.

\section{Beberapa Studi Tentang Musik Dalam Islam}

Dalam bahasa Yunani, musik tidak sekedar seni, tetapi memiliki cakupan yang sangat luas, seperti pendidikan, ilmu, tingkah laku yang baik, bahkan dipercaya sebagai seuatu yang memiliki dimensi ritual, magis dan etis. Hal inilah barangkali yang menjadi alasan al-Mubarrak dalam Muhaya (2003: 17) menulis at-Tashawwuf al-Islam fi al-Adab wa al-Akhlaq menggunakan istilah al-Musiq wa al-Ghina ketika membahas al-Sama dalam Tasawuf. Buku lain adalah Bawariq al-Ilma fi al-Rad 'ala Man Yucharrim bi al-Ijma' (kilauan cahaya yang sangat terang dalam menolak orang-orang yang mengharamkan al-Sama melalui ijma) yang ditulis oleh Ahmad alGhazali adik Imam Muhammad al-Ghazali.

Dalam bukunya Ahmad al-Ghazali membantah pendapat yang mengharamkan musik. Buku tersebut ditujukan kepada orang-orang yang mengharamkan musik, supaya mereka dapat mengubah sikap dan pandangannya yang tadinya mengharamkan musik menjadi simpati dan mengamalkannya karena cahaya ilahi. Hal tersebut disebabkan karena kata bawariq adalah bentuk jamak dari barqun yang berarti "sesuatu yang mula-mula muncul bagi seorang hamba dari berbagai kilauan cahaya ilahi". Dengan serta merta seorang hamba tersebut tertarik untuk masuk kedalam kedekatan Tuhan untuk mengadakan perjalanan ke hadhirat Allah SWT.

Menurut Muhaya (2003:18) bahwa kata "al-ma" berarti cahaya yang sangat terang yang menyinari para sufi pemula dan sinar tersebut tidak hanya berkesan pada imajinasi saja, tetapi menambah juga pada indera bersama sehingga sufi tersebut dapat ber-musyahadah melalui indera lahir. Dengan demikian, maksud dari "bawariq al$m a^{\prime \prime}$ adalah imunisasi cahaya Allah SWT. Yang sangat terang dan diterima dan karenanya ia dapat ber-musyahadah melalui kesan yang diperoleh oleh indera bersama (common sense) dan akhirnya diteruskan ke relung hati. Adapun kata ijma dalam akhir nama kitab ini menunjukan bahwa ulama yang mengharamkan musik memiliki landasan hukum yang kuat yaitu ijma. Untuk menangkis pendapat tersebut Ahmad alGhazali melalui risalah-nya menyangkal dengan cara mengajukan dalil-dalil kehalalan musik yang berasal dari al-Quran. Al-Hadits, perbuatan para sahabat, tabi'in, dan para ulama sufi sera dalil-dalil rasional yang menunjukan manfaat musik dalam peningkatan kualitas spiritual (Ainusyamsi, 2008: 13). Kitab Bawariq al-Ilma yang ditulis oleh Ahmad al-Ghazali membahas beberapa persoalan, yakni 1) pengertian al-Sama dan alasan mengapa para sufi melakukan kegiatan tersebut; 2) syarat-syarat yang harus dipenuhi sebelum melakukan kegiatan al-Sama; 3) tata cara dalam melakukan alSama; 4) alat musik yang digunakan dalam melakukan al-Sama; 5) faidah melakukan al-Sama; 6) Dalil-dalil yang mendukung kehalalan al-Sama; dan ke 7) kritik dan saran terhadap praktik al-Sama.

Dalam buku The Translation of Islamic Spirituality: Manifestation yang disunting Seyyed Hossein Nasr, seorang penulis bernama Jean-Louis Michon menulis tentang "Musik dan Tarian Suci Dalam Islam" dan telah memberi gambaran rinci tentang permasalahan yang berhubungan dengan musik ruhiyah (sufistik) dimulai dengan beberapa tokoh filsuf maupun sufi yang menggandrungi musik perenungan dan penyucian jiwa. Selain itu dijelaskan kekuatan musik bagi kehidupan manusia. Kemudian 
buku The Haritage of Sufism: The Legacy of Medieval Persian Sufism tulisan Leonard Lewisohn dalam Ainusyamsi (2008:14) menjelaskan tentang pandangan umum Islam Iran dan Sufisme Persia.

Laeman (2004) telah melakukan penelitian tentang Islamic Aesthetics. Dalam salah satu analisanya, dia mengutarakan tentang musik dalam estetika Islam. Menurutnya, musik telah menjadi isu penting dalam pemikiran Islam sejak awal kelahiran Islam itu sendiri. Dalam bukunya, Laeman juga mengkaji teori-teori dasar musik yang muncul dalam Filsafat Islam, di antaranya teori musik al-Farabi, Ibnu Sina, Ikhwan al-Shafa dan al-Kindi. Teori tentang musik juga dikemukakan oleh Djohan (2006) dalam bukunya yang berjudul Terapi Musik: Teori dan Aflikasi. Dalam buku tersebut diuraikan 1) mengenal terapi musik; 2) proses dan langkah-langkah dalam terapi musi; 3) aplikasi terapi musik.

Tulisan lain tentang musik adalah karya Gazalba (1987) yang menuangkan pemikirannya dengan analisa yang tajam dalam bukunya Islam dan Kesenian. Dalam bukunya itu secara gamblang dan luas dia mengupas secara rinci tentang relevansi seni dengan Islam. Gazalba tidak hanya semata-mata mengetengahkan pemikiran dan pendapatnya saja, tetapi juga mengutip nash kandungan al-Quran dan al-Hadits demi untuk menjelaskan bagaimana hubungan antara Islam dan Kesenian.

\section{Perkembangan Pemikiran Seni Musik}

Ibnu Sina dalam bukunya al-Syifa dan al-Najat menulis tentang musik. Sementara muridnya yaitu Abu Manshur ibn Zailah tahun 1048 menulis kitab al-Kafi fi al-Musiqa yang menulis tentang praktik seni musik. Pada abad yang sama Ibn al-Chaitam tahun 1039, menulis buku Risalah fi Ta'tsirat al-Luchun al-Musiqiyah fi al Nufus al Chayawaniyyah sebuah risalah dalam bidang musik. Khaza- nah musik Islam terus berkembang setelah seorang ahli musik dari Andalusia Ibn al-Sid tahun 1066 menulis beberapa pasal tentang seni musik dan alat alat musik dalam kitabnya al-Mukhashshash, kemudian Abu al Salt Umayyah al-Andalusi tahun 1134 seorang ahli dalam teori dan praktek musik menulis Risalah fi al-Musiqi. Kemudian Ibnu Bajah seorang filsuf mengarang kitab al-Musiqa sebuah kitab musik yang terkenal di Barat sebagaimana terkenalnya kita al-Musiqa karya Al-Farabi di Timur.

Dalam sejarah perkembangan seni musik di dunia Islam dapat dijumpai nama-nama besar ulama yang ahli dalam bidang musik seperti Abu al-Chakam al-Bachili (lahir tahun 1155), Ibn al-Naqqash al-Baghdadi (lahir 1178), Muhammad Ibnu Abi al Chakam (lahir 1180), Kamal al-Din Ibn Man'ah (lahir 1156) dan 'Alam al-Din Qaisar (lahir 1251). Selain itu terdapat juga beberapa ulama sufi yang membahas seni musik (al-Sama') dan pemanfaatannya yaitu Abu Thalib al-Maliki (lahir 998), Abu Nashr al Sarraj (lahir 988), Abu al-Karim Ibn Hawazin al Qusyairi (lahir 1072), al-Hujwiri (lahir 456), Abu Chamid alGhazali (lahir 1111), Ahmad al-Gazali (lahir 1121) Jalal al Din Rumi (lahir 672), dan Muhammad al-Syadzili al-Thunisi (lahir 882) (Muhaya, 2003: 10-11).

Bagi kaum sufi, musik memiliki fungsi yang beragam, yaitu membawa jiwa ke alam realitas, menyejukan hati, mengeluarkan permata ilahiyah yang tersimpan dalam relung hati, membersihkan hati dan meningkatkan kerinduan serta kecintaan kepada Allah SWT. Bahkan musik juga dijadikan sebagai sarana untuk mendekatkan diri kepada Allah SWT dan untuk mencapai derajat wushul (Ainusyamsi, 2008: 33)

Dalam perkembangan sejarah, Ikhwan al-Shafa dalam Muhayat (2003:22) mengelompokan sejarah musik dalam dua madzhab pemikiran yaitu: Pertama, madzhab revelationism. Madzhab ini memercayai bahwa musik berasal dari alam metafisika 
melalui tersibaknya tabir (draw back the veil) atau pewahyuan. Menurut madzhab ini, musik merupakan bunyi yang dihasilkan oleh gerakan jagat raya yang menimbulkan suara yang indah (nyanyian), yang harmonis, terpadu, silih berganti dan enak didengar. Musik yang dihasilkan oleh gerakan jagat raya berfungsi untuk membahagiakan jiwa ahli langit, malaikat, dan jiwa-jiwa yang bercahaya (al-nafs al-basithah), yaitu jiwa-jiwa yang substansinya lebih mulia dari pada substansi alam jagat raya. Lebih jauh menurut Ikhwan al-Shafa, pada alam inilah roh-roh itu hidup dan memperoleh kebahagiaan serta kenikmatan. Sekiranya suara yang dihasilkan oleh gerakan planetplanet dan bintang-bintang itu bukan suara yang indah (nyanyian), niscaya penghuni planet-planet dan bintang itu tidak tahan untuk mendengarkannya. Hal itu karena penghuni planet tadi memiliki kemampuan mendengar dan membaca tashbih baik siang maupun malam.

Pendapat Ikhwan al-Shafa di atas seiring dengan pendapat Phythagoras seorang filsuf Yunani (572-497 SM). Menurut Phythagoras, filsafat adalah kebahagiaan yang sejati, sedangkan jalan keselamatan dan pemurnian adalah musik yang paling tinggi. Ini berarti bahwa alat yang paling penting utama untuk membersihkan jiwa (ruch) agar mencapai kebahagiaan adalah musik. Lebih jauh Phythagoras mengatakan bahwa suara-suara itu adalah aksiden ('aradh) yang bertempat pada substansi melalui gerakan. Putaran ruang angkasa yang menggerakan planet-planet dan bintang-bintang itu memiliki "ritme", serta menghasilkan musik yang mengagungkan dan memuliakan Tuhan. Menurut Muhaya (2003: 24) pendapat Phythagoras dan Ikhwan al-Shafa sejalan dengan al-Quran (QS, 24: 41), dalam ayat ini Allah SWT menyatakan bahwa segala apa yang di langit dan di bumi serta burung bertasbih dengan cara memuji Allah SWT melalui bahasa yang tidak kita fahami.
Phythagoras mengatakan bahwa musik dapat menghantarkan pendengaran ke tingkat spiritualitas yang paling tinggi (maqam $m a^{\prime}$ rifah). Musik juga dapat berfungsi sebagai washilah atau jalan pengatur kehidupan manusia di dunia ini maupun di kehidupan yang ada di alam mitsal. Pemikiran Phythagoras ini diikuti oleh al-Rumi, menurutnya musik adalah makanan bagi pecinta Tuhan, karena di dalamnya terdapat fantasi ketenangan jiwa. Melalui aktivitas mendengarkan musik, dalam diri pendengarnya akan terhimpun suatu kekuatan yang besar. Kekuatan ini tidak dalam bentuk imajinasi tetapi sudah dalam wujud aksi (perbuatan). Di samping itu gelora cinta pun dapat meningkat melalui iringan musik, nyanyian yang romantik (Ainusyamsi, 2008: 35)

Madzhab revalationism memiliki beberapa argumen tentang musik. Pertama, dalam suatu hadits diriwayatkan oleh al-Thirmidzi dari Qatadah disabdakan: "Allah tidak mengutus seorang nabi kecuali (ia) memiliki suara indah". Dari keterangan tersebut diketahui bahwa para nabi memiliki suara yang indah dan suara yang indah adalah musik. Berdasarkan beberapa keterangan bahwa Nabi Daud AS tenggorokannya ibarat seruling yang merdu sehingga binatang binatang liar, burung-burung, jin, dan manusia berbondong-bondong dan berkumpul untuk mendengarkan bacaan Kitab Zabur yang dilantunkannya.

Teks suci seperti Kitab Zabur dan alQuran keduanya mengandung musik. Sebab keindahan suara yang disebabkan oleh bacaan keduanya bergantung pada keindahan yang inheren dalam teks kitab tersebut, sebab sebuah bacaan akan memesona jika terdapat harmoni antara keindahan suara dan teks. Karena itulah keindahan suara nabi Daud AS ketika membaca Kitab Zabur tidak dapat dipisahkan dari keindahan teks Zabur itu sendiri. Keindahan teks samawi juga dapat kita temukan dalam kitab suci al-Quran. Dalam al-Quran aturan panjang 
pendek dalam membacanya dan juga harmoni bunyi fashilah dalam ayat - ayatnya. Dalam membaca al-Quran seseorang diwajibkan membaca sesuai dengan kaidah Ilmu Tajwid. Bila al-Quran dibaca dengan tajwid yang benar, maka akan menghasilkan musik yang indah, sebab dari bacaan tersebut akan terdengar suara yang harmonis dan indah yang muncul dari keindahan teks yang terdapat dalam al-Quran (Muhaya, 2003: 26).

Madzhab ke dua dalam seni musik adalah naturalism. Menurut madzhab ini, manusia melalui fitrahnya dapat menciptakan musik. Aliran ini beranggapan bahwa kemampuan manusia untuk menciptakan musik merupakan fitrah, sebagaimana kemampuan untuk melihat, mencium, mendengar dan berjalan. Menurut Muhaya (2003: 26) aliran naturalism ini dapat dilihat dari pemikiran al-Faraby yang mengatakan bahwa musik itu muncul dari tabi'at manusia dalam menangkap suara yang indah yang ada di sekelilingnya (musik). Hal tersebut serupa dengan teori ding-dong dari Max Muller (1883-1900) yang mengatakan bahwa getaran udara yang ditangkap oleh pendengaran itu bagaikan pukulan pada sebuah lonceng yang menghasilkan bunyi (ding-dong). Musik muncul spontan ketika manusia mendengarkan suara-suara yang ada di alam raya seperti suara guntur, hujan, air terjun, ombak lautan, ranting pohon dan dedaunan. Melalui tabiatnya manusia membuang suara yang tidak disukainya (suara yang tidak mengandung musik) dan menerima suara indah (musik). Manusia pun selalu meniru apa yang disukainya. Menurut al-Rahmuni melalui daya kreativitasnya manusia kemudian memadukan suara yang satu dengan yang lainnya dalam susunan yang harmonis, yang akhirnya melahirkan musik.

Kedua madzhab memiliki implikasi yakni bahwa yang pertama menganggap musik sebagai seni suara dan sekaligus sebagai sesuatu yang magis, ritual, dan memiliki per- talian yang erat dengan agama. Sementara madzhab yang kedua, berpendapat bahwa musik adalah bagian dari budaya manusia kerena tumbuh dan berkembang bersamaan dengan pertumbuhan dan perkembangan manusia. Bagi kelompok pertama musik dianggap sakral sedangkan kelompok kedua musik dianggap sesagai sesuatu yang profan.

\section{Nilai Seni Musik}

Menurut Ainusyamsi (2008: 17) musik dapat dinilai karena termasuk seni yang mampu membangun keselarasan, keseimbangan dan keindahan peradaban manusia. Seni musik juga dinilai sebagai seni surgawi, sementara seni yang lain tidak disebut seperti itu. Menurutnya, yang jelas Tuhan ada dalam semua jenis kesenian dan ilmu pengetahuan. Namun hanya seorang musisi sufistik saja yang mampu "melihat" Tuhan bebas dari segala bentuk dan pemikiran. Dalam setiap kesenian yang lain terdapat nilai pengidolaan. Setiap pemikiran, setiap kata, memiliki bentuk nilai. Setiap kata dalam bentuk puisi membentuk sebuah gambar dalam pikiran, dan gambaran itu adalah nilai itu sendiri.

Musik tak lebih kecil nilai nya dari gambaran Sang Kekasih, karena musik adalah gambaran Sang Kekasih. Maka jika seseorang menyukai musik karena ia menyukai Sang Kekasih itu, lalu apakah Kekasih itu? Atau dimana Kekasih itu? Kekasih adalah yang menjadi "sumber nilai" dan tujuan kita. Apa yang kita lihat dari Kekasih didepan mata ragawi kita adalah keindahan yang ada di depan kita. Bagian dari Kekasih kita yang tidak berujud dalam mata kita adalah bathiniah dari keindahan nilai yang diwahyukan Sang Kekasih kepada kita melalui Nabi SAW (Ainusyamsi, 2008: 18)

Oleh karenanya, karena keterbatasan manusia, ia tidak akan mampu melihat "wujud" Tuhan secara ragawi di dunia fana ini, dan jika ingin "melihat" Tuhan di dunia ini 
lihatlah Dia dalam bentuk kreasi-Nya dan seluruh citaan-Nya, sebab segala yang dicintai di dalam warna, baris dan bentuk, atau "kepribadian"-segala yang dicintai dan bernilai adalah milik dari "keindahan sejati" yang merupakan Kekasih seluruh makhluk (Khan, 1996: 3-4). Ketika menelusuri sesuatu yang menarik dari keindahan ini yang dilihat dalam semua bentuk, maka akan diketahui, bahwa ini adalah gerak keindahan yang menggambarkan betapa agungnya nilai musik itu. Segala bentuk sifat, bungabunga yang dibentuk dan diwarnai begitu sempurna, planet, bintang, bumi, semuanya memberikan gagasan tentang keselarasan, tentang nilai musik.

Bila nilai musik diikuti dan dijiwai oleh para seniman musik, maka tidak diperlukan lagi nilai eksternal. Suatu hari musik akan menjadi sarana untuk mengekspresikan agama universal, dan suatu ketika akan muncul bahwa musik dan falsafahnya menjadi "agama" manusia, sebagai konstelasi nilai "efikasi musikal" terhadap pembinaan kepribadian sufistik. Pengertian tentang nilai musik, menunjukan bahwa musik berada pada kedalaman eksistensi manusia. Musik ada di balik karya seluruh alam semesta. Nilai musik bukan hanya sekadar objek terbesar kehidupan, namun juga kehidupan itu sendiri (Khan, 1996: 15).

\section{Unsur Unsur Seni Musik}

Dalam menjelaskan unsur-unsur pokok yang terdapat dalam musik, para ahli berbeda dalam memberikan penjelasan. Ikhwan al-Safa misalnya menyatakan bahwa musik adalah suara yang mengandung lagu (lahn), nada (naghm) dan cengkok (iqa'at). Lain halnya dengan Ikhwan al-Safa, al-Farabi menjelaskan bahwa musik adalah lagu (alalhan), yaitu kumpulan ritme yang disusun dengan urutan dan ketentuan tertentu. Oleh karena itu, lagu dan ritme merupakan sumber utama bagi musik (Muhaya, 2003: 28).
Secara ontologis, musik merupakan perpaduan antara unsur material dengan immaterial, ia tersusun dari elemen-elemen yang bersifat jasmaniah dan rohaniah. Oleh karena itu, musik mempunyai kekuatan untuk menspiritualkan hal yang materi dan sebaliknya mematerialkan yang spiritual. Adapun esensi musik itu berupa substansi rohaniah, yaitu jiwa pendengar.

Dalam tradisi keagamaan sering dibedakan antara musik vokal (suara manusia) dan musik yang dihasilkan oleh instrumen. Biasanya musik jenis pertama lebih tinggi nilainya dari pada yang kedua. Keutamaan musik vokal disebabkan oleh kemampuan kapasitasnya dalam berkomunikasi dengan makna (pesan). Menurut al-Farabi, dilihat dari fungsinya, musik yang digunakan oleh pendengarnya, pertama, sebagai alat untuk menghibur diri. Ini adalah fenomena yang sering kita jumpai. Ke dua, musik yang bertujuan untuk terjadinya suatu aksi dan reaksi. (perbuatan tertentu). Ketiga, musik yang membangunkan atau membangkitkan imajinasi. Ketiga jenis musik itu terangkum dan termuat dalam suara manusia. Di samping alasan di atas, keutamaan musik vokal juga disebabkan sumber musik. Pengikut pendapat ini berkeyakinan bahwa musik vokal lebih mulia dari pada musik instrumental karena keutamaan sumbernya. Musik vokal bersumber dari manusia, sedang musik instrumental bersumber dari benda. Karena manusia lebih mulia dari pada benda, musik vokal pun lebih mulia. Disamping itu sumber musik vokal diciptakan oleh Tuhan, sedangkan instrumen diciptakan oleh manusia.

Apresiasi terhadap musik vokal, secara historis, sudah ada sejak pra-Islam baik di kalangan bangsa Arab maupun bangsabangsa lain. Posisi tersebut tidak bergeser pada masa Islam. Hal itu dapat kita lihat pada sikap Nabi Muhammad SAW penyampai risalah keislaman. Nabi Muhammad SAW membiarkan kehadiran penyanyi di 
hadapan isterinya. Nabi pun pernah meminta salah seorang sahabat untuk melantunkan khuda dikala beliau sedang naik unta (Muhaya, 2003: 31)

Machlis dalam Muhaya (2003:28) lebih detail menjelaskan unsur-unsur penting yang ada dalam seni musik. Menurutnya, musik mempunyai lima materi pokok yaitu: pertama, Musical line, yakni lagu, atau pergantian nada-nada yang dirasakan oleh akal sebagai sesuatu yang ada "entity", lagu yang ada dalam musik disebut seagai roh nya musik. Kedua, musical space, adalah harmoni. Menurut Phytagoras, harmoni ini terletak pada nada-nada yang serasi dan sebanding dengan panjang dawai dalam bentuk bilangan yang sederhana, seperti "oktav" adalah 2:1, fifth adalah 3:2, atau fourth adalah 4:3. Hubungan ini disebut armonia yang kemudian menjadi istilah harmoni. Ketiga, musical times, yaitu ritme yang terdiri dari ketentuan perpindahan musik dalam waktu. Ritme merupakan suatu aturan dalam pengorganisasian dan pembentukan lagu, serta berfungsi mengontrol jarak antara nada satu dengan nada berikutnya. Ritme ini diulang-ulang dapat memengaruhi pendengarnya. Keempat, musical face, yaitu tempo. Tempo adalah ketentuan dari kecepatan sebuah musik. Tempo mempunyai implikasi emosional. Kelima, musical color, yaitu timbre. Nada yang sama akan menghasilkan suara yang berbeda ketika nada tersebut disuarakan melalui terompet atau biola. Perbedaan ini terletak pada sifat warna nada yang dimiliki oleh setiap instrumen. Timbre ini berfungsi untuk memfokuskan impresi musik yang kita alami. Warna nada ini mengarahkan imajinasi gaya suara kepada karakter khusus yang dimiliki.

\section{Manfaat Seni Musik}

Minimal ada tiga manfaat dari musik. Pertama, musik bermafaat antara lain untuk hiburan (tasliyah). Hiburan bukan semata- mata menampilkan sesuatu hanya sekedar kegembiraan secara lahiriah semata, akan tetapi hiburan yang mendidik, membina karakter prilaku maupun kepribadian. Seseorang jika mendengarkan musik merasa terhibur hatinya, secara psikis ia akan terasa adanya perubahan jiwa, disebabkan karena adanya refleksi emosi. Menurut Djohan (2005: 39), emosi adalah salah satu aspek yang paling meresap dalam eksistensi manusia, dalam arti yang berhubungan dengan setiap aspek perilakunya yang meliputi aksi, persepsi, memori, belajar, dan dalam membuat keputusan.

Musik diakui atau tidak, dapat meningkatkan perasaan, khususnya secara langsung dan cepat menimbulkan rasa senang. Meyer dalam Djohan (2005: 41) mengatakan bahwa semakin besar ketegangan yang ditimbulkan, semakin besar pula pelepasan emosi terhadap resolusi. Peran emosi dalam proses ini sangat kompleks. Dimensi pokoknya terletak pada ketegangan yang dibangun serta resolusi atau pelepasannya baik dalam musik itu sendiri maupun pendengarnya. Biasanya, bila terjadi resolusi, maka akan diikuti oleh relaksasi.

Manfaat musik yang ke dua adalah sebagai terapi. Proses terapi musik berawal dari adanya permintaan untuk memeroleh terapi, baik dari dokter, psikolo, ahli psikologi, ahli gangguan wicara, guru, orang tua, pekerja sosial, atau dari klien yang bersangkutan. Seorang terapis musik dituntut untuk memahami benar mengapa dan oleh siapa seorang klien dirujuk untuk memperoleh terapi. Terapi musik dapat dilakukan dengan menggunakan aneka macam alat musik, genre musik, pendekatan, metode, sistem aliran, maupun falsafah. Seorang terapis musik harus dapat mengombinasikan beberapa kemungkinan untuk mendapatkan strategi yang paling sesuai. Setiap terapis musik memiliki kebebasan untuk merancang dan melakukan modifikasi dalam terapi musik. Dalam strategi musik, musik di- 
gunakan untuk mencapai dua tujuan yaitu menguatkan prilaku yang diinginkan, atau mengadakan prilaku yang tidak diinginkan. Oleh karena itu, sesuai Teori Belajar sejumlah literatur menggunakan istilah reward atau reinforcement untuk musik sebagai penguat, atau punishment untuk musik atau perlakuan khusus melalui aktivitas musik yang dimaksudkan untuk meniadakan atau mengurangi perilaku (Djohan, 2006: 106).

Aktivitas musik merupakan latihan menyeluruh otak dan pikiran yang dapat menguatkan sistem jaringan otak. Di samping meningkatkan kapasitas kinerja otak dengan memperkuat hubungan antar neuron, pengaruh musik terhadap kerja otak juga merupakan bagian dari pengaruh musik terhadap kognisi dan perilaku kepribadian seseorang. Banyak publikasi mengenai pengaruh musik terhadap seseorang baik melui membaca, bermusik, dan bernyanyi dalam kelompok paduan suara, karena juga berhubungan langsung dengan kesehatan. Belin dari Service Hospitalier Frederic Joliot di Osray, mengatakan bahwa saat ini telah ditemukan jenis musik tertentu yang memiliki manfaat untuk mengubah fungsi otak. Yayasan Melodic International Theray dalam publikasinya mengenai keberhasilan terapi musik pada pasien gangguan bicara akibat stroke mengatakan bahwa gaya musik yang digunakan sebagai treatment (perlakuan) berkarakter melodi yang kuat.

Carlyle dalam Rachmawati (2005: xxxii) menempatkan musik sebagai medium yang membangkitkan perasaan religious yang menghubungkan manusia dengan ilahi. Sedangkan Burton memandang bahwa musik memiliki daya penyembuh bagi gangguan emosional. Kemudian Congreve (1967: 1) menilai musik bukan hanya pada manusia sebagai salah satu penghuni alam, musik juga memberi pengaruh pada alam. Dalam pandangan metafora, musik mampu menghaluskan benda sekeras karang, memberi lukisan indah yang mengurai kusutnya ja- linan temali pohon. Di sini tertangkap kesan Congreve tentang peran musik yang seakan mampu meperhalus dunia.

\section{Seni Musik Dan Pendidikan Nilai di Pesantren}

Banyak pesantren memandang positif terhadap pengembangan seni musik, terutama musik sufistik. Hal itu disebabkan karena musik sufistik secara syar'i tidak bertentangan dengan substansi nilai nilai agama Islam, juga dapat dijadikan sebagai media dalam pembinaan mental reliji. Pada prakteknya musik sufistik di pesantren diterapkan sebagai proses internalisasi (riyadhah) nilai-nilai pendidikan bagi santri, seperti yang dilakukan di Pondok Pesantren Darusalam Ciamis dengan mengambil materi dari Qosidah Burdah (Ainusyamsi, 2008: 6-7).

Penanaman nilai-nilai di pesantren merupakan bagian dari esensi pendidikan umum. Nilai-nilai di pesantren dapat dibinakan dalam berbagai bentuk, seperti nilai doktrin/ajaran, nilai budaya, nilai sastra dan nilai musik. Pesantren adalah sebuah tempat penggemblengan santri yang merupakan aset pendidikan dan pencerdasan umat. Pesantren merupakan institusi pendidikan yang memprioritaskan pendidikan nilai-nilai agama di samping mengembangkan nilai-nilai non agamis lain yang bersifat positif. Prioritas pendidikan nilai agama dianggap penting, karena nilai-nilai ini yang menjadi pondasi dalam konstruksi kepribadian santri, sehingga dengan sendirinya ia mampu secara mandiri mengorientasikan diri menjadi manusia yang paripurna (insan kamil) di kemudian hari.

Pesantren berusaha mengoptimal penanaman nilai-nilai agama dalam diri santri. Adapun nilai-nilai yang ditanamkan di antaranya nilai teologia (ushul al-din), nilai yuridis (figh), nilai sosio kultural Islam, nilai sufistik dan lainnya. Pada tataran aplikasinya, semua nilai tersebut ditanamkan secara proporsional dan berkesinambungan. Secara 
seimbang dimaksudkan bahwa nilai-nilai yang ada diinternalisasikan sesuai dengan kompetensi kognisi, afeksi, dan psikomotor santri, sehingga potensi akal, kalbu, dan amal santri dapat berkembang selaras secara psikologis dan fisiologis.

Nilai teologis (ushul al-din) ditanamkan dengan tujuan untuk mengonstruksi paradigma keimanan santri, sehingga ia mampu konsisten terhadap ajaran al-Quran dan Sunnah secara murni, beriman kepada Allah Yang Maha Esa, tanpa ditulari perilaku bid'ah, khurafat, dan takhayul. Nilai yuridis (figh) ditanamkan dengan tujuan untuk membentuk pribadi santri yang faham dan taat hukum baik dalam ibadah maupun mua'malah, serta mampu mengontrol diri untuk tidak melakukan hal-hal yang dilarang agama. Nilai sosio kultural Islam ditanamkan dengan tujuan untuk membentuk pribadi santri yang mampu mengembangkan diri sebagai makhluk sosial, yang dengan eksistensi dirinya ia dapat bermanfaat bagi lingkungan dan masyarakat, serta mampu mengemukakan solusi terhadap problematika sosio-budaya di masyarakat. Nilai sufistik ditanamkan dengan tujuan untuk membentuk pribadi santri yang mampu mengorganisir qalbunya agar bersih dari segala kotoran hati dan penyakit jiwa, baik yang muncul dari syahwat, godaan syetan, dan nilai-nilai buruk dari kehidupan masyarakat serta dampak negatif modernisasi dan globalisasi.

Proses penanaman nilai sufistik di pesantren salah satunya melalui pengajian mingguan dan kajian Kitab Islam Klasik beserta praktiknya (Ainusyamsi, 2008: 2-3). Nilai-nilai sufistik yang semula ditanamkan melalui penerapan pengajian tradisional, yaitu hanya dengan membacakan (logat), kemudian dijelaskan pemahamannya. Namun untuk memberikan gairah pendalaman serta pemaknaan terutama untuk pencerahan jiwa bagi para santri, di pesantren dilaksanakan internalisasi nilai nilai sufistik me- lalui musik. Salah satu contor nya adalah musikalisasi Qosidah Burdah seperti yang dilakukan di Pondok Pesantren Darusalam Ciamis.

Menurut Dr. Fadlil Yani Ainusyamsi pemimpin Pondok Pesantren Darusalam Ciamis, Qosidah Burdah di pesantrennya di-riyadhah-kan melalui cara musikalisasi bait-bait di dalamnya. Penanaman nilai bahkan sampai pada pengobatan/terapi melalui media seni musik (al-Sama') sebenarnya sudah cukup lama dilaksanakan di kalangan ulama masa lalu seperti al-Farabi, al-Kindi, Ibnu Sina, Ibnu Bajah, Ibnu Khaldun, al-Gazali, Jalaluddin Rumi, Ibnu Arabi, Ikhwan al-Shafa, Shafyu al-Din, dll. Selanjutnya sebagai upaya untuk melaksanakan pendidikan nilai di Pondok Pesantren Darusalam Ciamis, dilakukan pembinaan mental reliji melalui musik. Hal ini dilakukan sebagai upaya untuk penanaman pendidikan mental dalam rangka memberikan pemahaman sikap keberagamaan dan perkembangan serta pertumbuhan seseorang. Selain pencegahan dari sifat-sifat buruk, materi pengajian diharapkan dapat pula bersifat menyembuhkan. Teknik menyembuhkan jiwa bagi santri yang sedang galau, resah dan depresi dengan cara mendeskripsikan nilai-nilai sufistik yang terpadu dalam musikalisasi Qosidah Burdah. Dalam beberapa pagelaran Musik Qosidah Burdah di Pondok Pesantren Darusalam Ciamis terdapat upaya penanaman nilai-ilai sufistik, seni musik tidak bebas nilai seperti yang sering terjadi di dalam pagelaran musik-musik pada umumnya.

Melihat fenomena yang ada, pada umumnya pagelaran musik sering dilaksanakan secara bebas nilai (values free) yaitu pagelaran musik yang cenderung hanya menampilkan yang bersifat hiburan semata-mata (entertainment) atau lebih tepat lagi cenderung pada pagelaran musik hura-hura (pell-mell musik). Oleh karena itu menurut pimpinan Pondok Pesantren Darusalam Ciamis Dr. K.H. Fadlil Yani Ainusyamsi, 
M.Ag., MBA, sebagai langkah penyeimbang (balance) bahwa internalisasi (riyadhah) nilainilai sufistik melalui musikalisasi pengajian tradisional di pesantren perlu untuk dikenalkan sebagaimana yang dilakukan di Pondok Pesantren Darusalam Ciamis dalam pembinaan santrinya.

Berdasarkan penelitian di lapangan, dalam syair musik qosidah burdah yang diajarkan di Pondok Pesantren Darusalam Ciamis terdapat nilai-nilai sufistik yang dapat diklasifikasikan menjadi dua, yaitu nilai-nilai sufistik dan nilai-nilai keteladanan. Pertama, nilai-nilai sufistik yang terkandung dalam musik qosidah burdah adalah 1) Syauq (kerinduan) yaitu rasa rindu yang bersumber dari hati. Ajaran Syauq terangkum dalam bait satu sampai dengan tiga; 2) mahabbah (kecintaan) yaitu rasa cinta yang lahir dari lubuk hati yang paling dalam. Ajaran mahabbah terdapat dalam bait ke empat sampai dengan dua belas; 3) tarku al-syahwat (menahan hawa napsu) terdapat dalam bait ke tiga belas sampai dengan dua puluh lima; 4) muhasabah al-nafs (introspeksi diri) yaitu upaya untuk memperhitungkan, menilai, mempertimbangkan atau menelaah diri sendiri. Di sini taubah merupakan upaya untuk meminta ampun kepada Allah SWT berdasarkan kesadaran bahwa dirinya bergelimang dengan dosa. Nilai-nilai sufistik tentang muhasabah al-nafs terdapat dalam bait ke dua puluh enam, dua puluh tujuh dan seratus empat puluh dua; 5) zuhud yaitu meninggalkan hal-hal yang sifatnya duniawi untuk menuju pada hal-hal yang sifatnya ukhrowi. Nilai sufistik tentang zuhud terdapat dalam bait ke dua puluh delapan dan seratus empat puluh tiga.

Nilai kedua dari nilai-nilai sufistik qosidah burdah adalah nilai keteladanan yang bersumber pada diri Nabi Muhammad SAW. Adapun nilai-nilainya adalah 1) pribadi yang zuhud, yaitu pribadi nabi yang tercermin dari nilai qurani pada al-Quran. Pribadi sufi ini terdapat dalam qosidah burdah bait ke dua puluh sembilan sampai tiga puluh empat; 2) Pribadi yang taqwa, yaitu upaya untuk mematuhi segala perintah Allah SWT dan menjauhi segala larangannya. Nilai sufistik tentang taqwa terdapat dalam bait ke tiga puluh lima; 3) pribadi yang selalu dicintai. Pribadi ini tergambar dalam bait ke tiga puluh enam; 4) pribadi yang I'tisham bi chablillah, yaitu berpegang teguh kepada ajaran Allah SWT. Pribadi sufistik ini terdapat dalam bait ke tiga puluh tujuh; 5) pribadi yang tawakal, yaitu menyerahkan segenap urusan pribadi kepada Allah SWT setelah melakukan usaha yang optimal. Pribadi ini terdapat dalam qosidah burdah bait ke tujuh puluh tujuh (Ainusyamsi, 2008: 100-101).

Contoh tema dan nilai yang terkandung pada bait-bait qosidah burdah diantaranya:

Bait ke-1

Tentang Syauq ( kerinduan )

A min tadzakkuri jiranin bi Dzi Salam

Mazajta dam'an jara bi muqlatin bi dami

Apakah sebab dikau ingat tetangga yang

berada di Dzi Salam

Hingga dikau mencampurkan air mata dengan darah yang menetes dari matamu

Syauq pada bait ke-1 digambarkan dengan kata tadzakkuri (ingat terus menerus), dam'an (air mata) dan dami (darah). Katakata tersebut mengindikasikan klimaks kerinduan, diilustrasikan dengan seorang yang terus menerus ingat kepada seseorang, yang ingatannya tak dapat hilang dari memorinya. Kata tadzakkur berasal dari kata dzakara yang berarti mengingat, kemudian diformulasikan dengan wajan isim masdar "tafa'ala" sehingga memiliki arti ingat "terus menerus". Klimak kerinduan ini disimbolkan dengan air mata yang bercampur dengan darah. Bentuk tangisan ini memiliki arti bahwa kerinduan yang sangat tidaklah diiringi dengan tangisan biasa. Tangisan air mata darah adalah tangisan yang berlarut-larut, di mana kerinduan hati tidak terpenuhi. Suatu khayalan indah dari seseorang yang memantulkan nostalgia terhadap sang kekasih yang tak berada di sisinya. 
Bait ke-12

Tentang machabbah ( kecintaan ) Innit-tahamtu nashichasy-syabi fi 'adzali Wasy-syaibu ab'adu fi nushchin 'anit tuhami Sesungguhnya aku mencurigai nasehat-nasehat itu, walau nasehat itu dari ubanku Sedang uban itu dalam menasehati tidak boleh dicurigai

Machabbah pada bait ke-12 di tampilkan dalam kalimat Innit-tahamtu nashichasy-syabi fi 'adzali (Sesungguhnya aku mencurigai nasehat-nasehat itu, walau nasehat itu dari ubanku). Uban merupakan tanda di kepala manusia yang menunjukan bahwa usia seseorang sudah tua. Uban menunjukan bahwa sejauh apapun upaya manusia meraih sesuatu akan keterbatasan yang menghalanginya, karena manusia bukanlah Tuhan yang tidak memiliki keterbatasan. Tuhan memberikan uban di kepala manusia sebagai peringatan akan adanya keterbatasan usia, dan manusia tidak dapat muda dan hidup abadi. Tetapi bagi orang yang dilanda cinta tidak akan mempedulikan tanda itu. Karena cinta dapat dibawa sampai mati, cinta membuat seseorang itu seolah-olah hidup walaupun dia telah mati. Cinta adalah tanda kekuasaan Tuhan bagi manusia yang dapat melewati batas usia. Begitu banyak monumen, bangunan, atau simbol di dunia yang menjadi lambang cinta sejati yang terus hidup, walaupun sang pemilik cinta telah tiada. Salah satu contohnya Taj Mahal.

\section{Bait ke-13}

Tentang tarku al-syahwat (menahan hawa nafsu )

Fa inna ammarati bis-su'i mat-ta'azhat

Min jahliha bi nadzirisy-syaybi wal-harami

Sesungguhnya nafsu amarahku

Tidak mau menerima nasehat dari ubanku dan sifat tuaku, sebab nafsu itu tolol

Pada bait ke-13 Qosidah Burdah, nafsu digambarkan dengan kalimat Fa inna ammarati bis-su'i mat-ta'azhat, Min jahliha bi nadzirisy-syaybi wal-harami (sesungguhnya nafsu amarahku itu tidak mau menerima nasehatnasehat dari ubanku dan sifat tuaku, sebab nafsu itu tolol ). Jika hawa nafsu menguasai jiwa seseorang, maka segala kebaikan tidak akan diterima, karena nafsu identik dengan kebodohan. Kebodohan bukan berarti tidak pandai atau tidak berilmu, tetapi adalah sikap "tidak mau tahu" akan kebenaran, karena nafsu akan mematikan logika yang sehat. Uban adalah tanda usia manusia, yang menjadi peringatan bagi manusia untuk tidak menghabiskan usia dengan hawa nafsu. Karena hawa nafsu selalu berakhir dengan kejelekan, maka Allah SWT memberikan tanda uban agar manusia sadar agar hidupnya tidak berakhir dengan su-ul khatimah.

Bait ke-26

Tentang muchasabah al Nafs (introspeksi diri) dan Taubah ( taubat)

Astaghfirullaha min qaulin bi la amalin

La qad nasabtu bihi naslan li dzi uqumi

Aku memohon ampunan kepada Allah dari perkataan tanpa amal

Benar-benar ucapan itu kuibaratkan anak yang keluar dari orang yang mandul.

Pada bait ke-26, muchasabah al-nafs dinyatakan pada kalimat Astaghfirullaha min qaulin bi la amalin dan naslan li dzi uqumi. Bahwa manusia harus me-muchasabah dirinya sendiri, yang sadar atau tidak sadar telah berbuat dosa, zalim, dan alpa, dan bahwa setiap manusia memiliki kekurangan masing-masing. Sikap muchasabah al-nafs mengalihkan perhatian kita untuk menzalimi orang lain dengan segala perbuatan buruk kita. Istighfar (memohon ampun) kepada Allah SWT merupakan proses lanjutan dari muchasabah al-nafs untuk membersihkan diri dari segala dosa, zalim dan alpa termasuk di dalamnya membersihkan diri dari sikap ketidaksesuaian perkataan dan perbuatan

Bait ke-30

Tentang pribadi yang zuhud (orientasi $u k h r o w i)$

Wa syadda min saghabin achsya-ahu wat thawa Tachtal hijarati kasychan muthrafal adami Orang itu ( Nabi SAW ) mengikat perutnya sebab lapar

Hingga ia mengikatkan batu di perutnya yang berkulit halus itu sekedar menahan lapar 
Salah satu prilaku zuhud yang dilakukan oleh Nabi Muhammad SAW yang terkandung dalam qosidah burdah bait ke-30 tertera dalam kalimat Tahtal hijarati kasyhan muthrafal adami (ia mengikatkan batu di perutnya yang berkulit halus itu sekedar menahan laparnya). Menahan lapar merupakan salah satu metode zuhud. Lapar lawan dari kenyang. Jika manusia kekenyangan maka otak dan hati akan tidur, sedangkan syahwat akan bangkit. Pusat syahwat berada di perut. Menahan lapar berarti usaha untuk mengendalikan syahwat, tetapi memperluas kesempatan bagi otak untuk berfikir dan hati untuk merasa. Nabi Muhammad SAW rela menahan lapar hingga melilitkan batu di perutnya untuk menahan perihnya lapar, sehingga kelaparan itu tidak mengganggu ibadahnya kepada Allah SWT.

\section{Bait ke-35}

Tentang pribadi yang taqwa

Nabiyyunal amirun nahi fa la ahadun

Abarra fi qawli la minhu wa la na 'ami

Nabi kita yang selalu memerintahkan

kebaikan dan selalu mencegah kemunkaran

Maka tiada seorang pun yang lebih baik

dalam perkataan dan perbuatan dibanding dengan beliau

Pada bait ini, taqwa terkandung dalam kalimat Nabiyyunal amirun nahi fa la ahadun, Abarra fi qawli la minhu wa la na 'ami Nabi kita (Muhammad SAW) yang selalu memerintahkan (kebaikan) dan selalu mencegah (dari kemunkaran). Maka tiada seorang pun yang lebih baik dalam perkataan dan perbuatan disbanding dengan beliau. Merupakan perintah Nabi Muhammad SAW kepada umatnya untuk selalu bersikap taqwa. Sebagian umatnya ada yang berlebihan atau di luar standar dalam melakukan ketaatan kepada Allah SWT, sehingga perbuatannya itu melanggar batas-batas fitrah manusia. Maka dalam hal ini, Nabi Muhammad SAW adalah contoh pribadi yang taqwa.

Bait ke-77

Tentang tawakkal (berserah diri)
Fash-shidqu fil ghari wash-shidqu lam yari Wa hum yaquluna ma bil ghari min arami Adapun orang yang benar (Nabi Muhammad SAW) dan yang membenarkan

(Abu Bakar AS) di dalam gua tiada pergi

Tetapi orang-orang kafir berkata bahwa di dalam gua itu tiada seorangpun tinggal

Bait ke-77 menggambarkan sekelumit kronologi hijrah Nabi Muhammad SAW yang ditemani Abu Bakar AS ke Yatsrib (Madinah). Pada saat hijrah, status Nabi Muhammad SAW adalah "buronan" kaum kafir Quraisy yang musti ditangkap hidup atau mati. Status ini diterapkan oleh orang kafir sebagai presedence dari konspirasi mereka untuk menghapus ajaran Islam dan pimpinannya. Semua kabilah di Mekah terlibat dalam konspirasi ini, sehingga memungkinkan untuk selamat sangat tipis sekali. Nabi Muhammad SAW tetap ikhtiar untuk keluar dari rumahnya, kemudian menempuh jalur yang tidak biasa ditempuh oleh suku Quraisy ke Madinah, sehingga Nabi Muhammad memutuskan untuk tinggal sebentar di Gua Tsur. Di dalam gua Nabi Muhammad SAW dan sahabatnya Abu Bakar AS berserah diri kepada Allah SWT akan nasib hidup mereka berdua dengan mengatakan:...."innallaha ma'ana" (sesungguhnya Allah SWT bersama kita). Kemudian Allah SWT pun mematahkan logika orang kafir dengan menghadirkan laba-laba ('ankabut) dan burung merpati (hamam) di mulut gua sehingga mereka yakin bahwa nabi dan sahabatnya tidak ada di gua.

Melihat bait-bait dari qosidah burdah diatas, terlihat sarat akan pesan moral dan nilai-nilai pendidikan. Nilai-nilai Syauq (kerinduan), machabbah (kecintaan), tarku alsyahwat (menahan hawa nafsu), muchasabah al-nafs (instopeksi diri), taubah (taubat), zuhud (orientasi $u k h r o w i)$, pribadi yang zuhud, pribadi yang takwa, pribadi yang tawakal dapat diinternalisasikan dalam kehidupan keseharian para santri di pondok pesantren, sebagaimana yang telah dilakukan di Pondok Pesantren Darusalam Ciamis. 


\section{PENUTUP}

Bagi santri dan warga pesantren lainnya, musik bukan hanya sekedar media hiburan semata, tetapi lebih luas dari itu dapat menjadi pembentuk prilaku positif. Hal tersebut disebabkan karena musik selain mampu melahirkan entertainment musik juga dapat melahirkan terapi musik. Selain bermanfaat dalam mengungkapkan perasaan, musik juga bisa menjad kreator untuk mewujudkan diri secara keseluruhan (self actualization) sebagai salah satu kebutuhan pokok hidup manusia.

Musik sendiri memiliki dimensi kreatif (al-janib al-ibtikary) dan memiliki bagian yang identik dengan proses belajar secara umum. Sebagai contoh, dalam musik terdapat analogi melalui persepsi, visual, auditori, antisipasi, pemikiran induktif-deduktif, memori, konsentrasi dan logika. Dalam musik juga dapat dibedakan serta dipelajari secara cepat-lambat, rendah-tinggi, keraslembut, yang berguna untuk melatih kepekaan santri terhadap stimuli lingkungan baik itu di pondok pesantren maupun di luar pondok pesantren.

Bagi santri atau masyarakat pesantren, seni musik dapat dijadikan sebagai alat untuk meningkatkan dan membantu perkembangan pribadi dan sosial santri. Perkembangan pribadi meliputi aspek kemampuan kognitif, penalaran, intelegensia, kreativitas, membaca, bahasa, sosial, perilaku, dan interaksi sosial.

\section{Daftar Pustaka}

\author{
Al-Qardhawy \\ 2001 Figh al-Ghina wa al-Musigy fi Dhau-I \\ al-Quran wa al-Sunah. Cairo: Makta- \\ bah Wahbah
}

Djohan

2005 Psikologi Musik. Yogyakarta: Buku Baik

2006 Terapi Musik: Teori dan Aplikasi. Yogyakarta: Galang Pres

Fadlil Yani Ainusyamsi

2008 Studi Tentang Internalisasi Nilai-Nilai Sufistik Melalui Musikalisasi Qosidah Burdah. Bandung: UPI

Gazalba

1998 Islam dan Kesenian: Relevansi Islam dan Seni Budaya. Jakarta: Penerbit Pustaka Al-Husna

Khan

1996 The Mysticism of Sound and Music. London: Boston Press

Muhaya

2003 Bersufi Melalui Musik: Sebuah Pembelaan Musik Sufi oleh Ahmad al-Gazali. Yogyakarta: Gama Media

Nakagawa

2000 Musik dan Kosmos: Sebuah Pengantar Etnomusikologi. Jakarta: Yayasan Obor Indonesia 